\title{
Synthesis and Properties of Addition-Type Poly(norbornene)s with Siloxane Substituents
}

\author{
By Hiroaki TETSUKA, ${ }^{*}$ Kenichi ISOBE, and Mamoru HAGIWARA
}

Vinyl addition copolymerization of norbornene with norbornene derivatives bearing siloxane substituent, three arm-, cyclicand phenyl-siloxane groups, was realized in the presence of the binary $\mathrm{Ni}(\mathrm{acac})_{2} / \mathrm{B}\left(\mathrm{C}_{6} \mathrm{~F}_{5}\right)_{3}$ system. The resulting copolymers show good solubility in common organic solvents and possess a very high grass transition temperature between 265 and $360^{\circ} \mathrm{C}$, depending on the content and structure of the siloxane groups. The incorporation of siloxane groups linked to the polymer chain results in a significant increase in the mechanical flexibility of the corresponding films. Furthermore, the gas permeability is also dependent on the content and structure of the siloxane groups, and the films obtained for the polymers with three arm-siloxane group $\left(-\mathrm{Si}\left(\mathrm{OSiMe}_{3}\right)_{3}\right)$ display high oxygen permeability in the range of 39 to 239 Barrer.

KEY WORDS: Polynorbornene / Siloxane Substituent / Copolymerization / Nickel Catalyst /

Norbornene can be polymerized by three different methods: ring opening metathesis polymerization (ROMP), cationic or radical polymerization, and vinyl addition polymerization. ${ }^{1}$ Among these polymers, addition-type poly(norbornene), presenting the rigid bicyclic structure, is recently attracting strong interest in optical and opto-electronic device applications because of high optical transparency, low birefringence, very high glass transition temperature and low dielectric constant. However, poor solubility in common organic solvents and mechanical brittleness are serious disadvantages for the processing of the polymer materials. These problems can be improved markedly by copolymerizing a small amount of functional norbornene derivatives.

So far, many types of poly(norbornene)s with functional groups have been prepared. ${ }^{2-13}$ Heitz et al. ${ }^{2,3}$ investigated the addition-type copolymerizations of norbornene with norbornene carboxylic acid esters, and found that the solubility of the copolymers and the thermal properties, such as glasstransition and decomposition temperatures, were dependent on the content as well as structure of the substituents. Risse et $a .^{4-6}$ came to the same conclusion by studying poly(norbornene)s containing hydroxyl, carboxylic acid and ester. Goodall et $a l . .^{7-9}$ and Grove et al. ${ }^{10}$ prepared alkyl- or alkoxysilyl-substituted poly(norbornene)s, which showed improved mechanical toughness and adhesion to common substrate materials. On the other hand, Dorkenoo et al. ${ }^{11}$ and Finkelshtein et al. ${ }^{12}$ investigated the homopolymers of norbornene derivatives bearing alkyl or alkylsilyl substituents, and demonstrated that the chain length and the bulkiness of the substituents played a decisive role in the transport properties, such as gas permeability and permselectivity, for the polymeric membranes. These results show that the nature of substituent and the content in the main chain are an important factor for the regulation of the material properties.
Poly(siloxane) is a class of polymers that has practical importance in the consumer and industrial applications for oil, membrane, rubber and powder. ${ }^{14}$ Since the polymer is composed of chemically stable and very flexible $\mathrm{Si}-\mathrm{O}-\mathrm{Si}$ backbone, the materials display many unique properties, such as heat resistance, weatherability, low temperature ductility, and high gas and vapor permeabilities. Those properties are usually not found with classic carbon-based polymer. Thus, it is expected that introduction of the siloxane chain into poly(norbornene) will give polymer materials with superior physical and transport properties. However, the search for poly(norbornene)s with siloxane group have not been reported, yet.

In this work, we have synthesized novel poly(norbornene)s with oligosiloxane groups via vinyl addition polymerization route (Figure 1), and characterized the solubility, thermal and mechanical properties of the obtained polymers. The norbornene derivatives with various siloxane substituents, three arm-, cyclic- and phenyl-siloxane groups, were used as monomers in order to study the influences of the structures of the siloxane groups on the polymerization process and on the material properties. In addition, the transport properties of these new polymers were investigated by monitoring the oxygen gas permeability of the corresponding films.

\section{EXPERIMENTAL}

\section{General Procedures and Materials}

All the experiments involving air- or moisture-sensitive compounds were performed using Schlenk or dry box techniques. $\mathrm{B}\left(\mathrm{C}_{6} \mathrm{~F}_{5}\right)_{3}$ was purchased from Tokyo Chemical Industrial Co., Ltd and used without further purification. Nickel bis(acetylacetonate) $\left(\mathrm{Ni}(\mathrm{acac})_{2}\right)$ was purchased from Aldrich and dehydrated under vacuum at $100{ }^{\circ} \mathrm{C}$. Solvents and Bicyclo[2.2.1]hept-2-ene (norbornene: NB) were purchased from Tokyo Chemical Industrial Co., Ltd, and degassed under

Silicone-Electronics Materials Research Center, Shin-Etsu Chemical Co., Ltd, Hitomi, Matsuida-machi, Annaka 379-0224, Japan

*To whom correspondence should be addressed (Tel: +81-27-384-5330, Fax: +81-27-384-5307, E-mail: htezuka@ shinetsu.jp). 


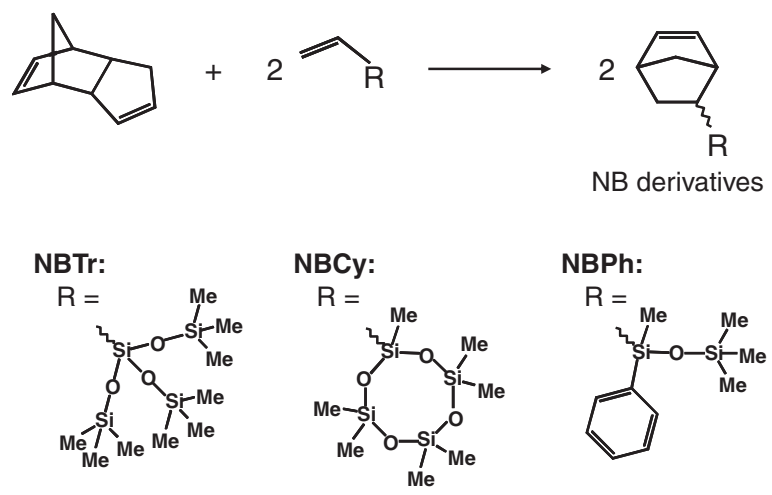

NB:

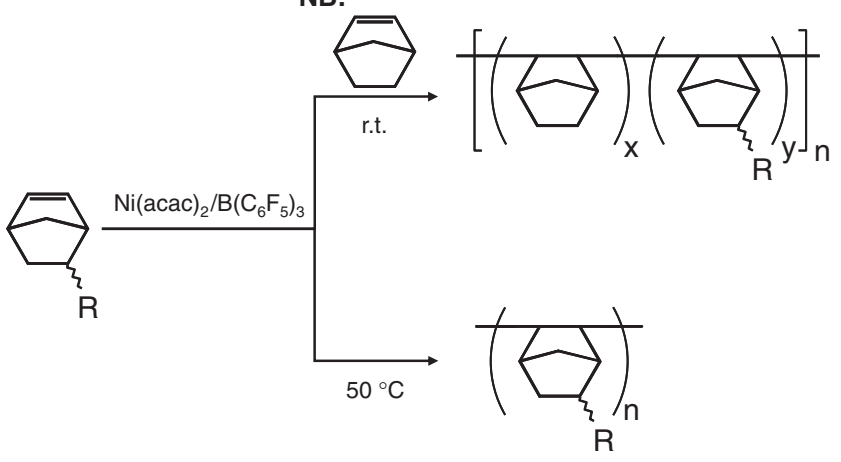

Figure 1. Schematic drawing of monomer and polymer preparations.

nitrogen and dried over $4 \AA$ molecular sieves before use. Basic siloxane and silane reagents were prepared by Shin-Etsu Chemical Co., Ltd.

\section{Norbornene Derivatives Bearing Siloxane Substituents}

5-Tris(trimethylsiloxy)silyl-2-norbornene (NBTr), 1-(2norbornen-5-yl)-1,3,3,5,5,7,7-heptamethylcyclotetrasiloxane (NBCy), and 5-(methylphenyltrimethylsiloxysilyl)-2-norbornene $(\mathrm{NBPh})$ were synthesized by the Diels-Alder reactions of dicyclopentadiene and the corresponding vinyl-functional silicon compounds (tris(trimethylsiloxy)vinylsilane, 1-vinyl1,3,3,5,5,7,7-heptamethylcyclotetrasiloxane, and methylphenyltrimethylsiloxyvinylsilane), respectively, and then isolated by vacuum-distillation (see Figure 1). The endo/exo-molar ratios of the monomers were determined by integration of the proton resonances of distinct peaks $(6.10-5.70 \mathrm{ppm}$ : $-\mathrm{CH}=\mathrm{CH}$-) (see Figure 2). ${ }^{4}$ These monomers were degassed under nitrogen and dried over $4 \AA$ molecular sieves prior to polymerization.

5-tris(trimethylsiloxy)silyl-2-norbornene (NBTr: endo/ exo $=60 / 40$, b.p. $118{ }^{\circ} \mathrm{C}$ at $5 \mathrm{mmHg}$, isolated yield: $75 \%$, G.C. purity: $>99 \%$ ) (Figure $2 \mathrm{~A}) .{ }^{1} \mathrm{H} \mathrm{NMR}\left(\mathrm{CDCl}_{3}\right): \delta 6.03-$ $5.79(\mathrm{~m}, 2 \mathrm{H},-\mathrm{CH}=\mathrm{CH}-), 2.82-2.68(\mathrm{~m}, 2 \mathrm{H}$, bridgehead $\equiv \mathrm{CH})$, $2.12-0.11\left(\mathrm{~m}, 5 \mathrm{H},=\mathrm{CH}-\mathrm{Si}-\right.$ and $\left.-\mathrm{CH}_{2^{-}}\right), 0.03--0.02(\mathrm{br} \mathrm{s}$, $\left.27 \mathrm{H},-\mathrm{Si}-\mathrm{CH}_{3}\right) .{ }^{13} \mathrm{C} \mathrm{NMR}\left(\mathrm{CDCl}_{3}\right): \delta 138.0-133.7(-\mathrm{CH}=\mathrm{CH}-$ : endo 138.0, 134.3, exo 135.1, 133.7), 51.0-46.7 (bridge $-\mathrm{CH}_{2}-$ : endo 51.0, exo 46.7), 44.6-42.4 (bridgehead $\equiv \mathrm{CH}$ : endo 44.7, 42.5, exo 43.1, 42.4), 27.1-26.8 (- $\mathrm{CH}_{2}-$ : endo 26.8 , exo 27.1$)$, 23.2-23.1 (=CH-Si-: endo 23.1, exo 23.2), $1.87\left(-\mathrm{Si}-\mathrm{CH}_{3}\right)$.
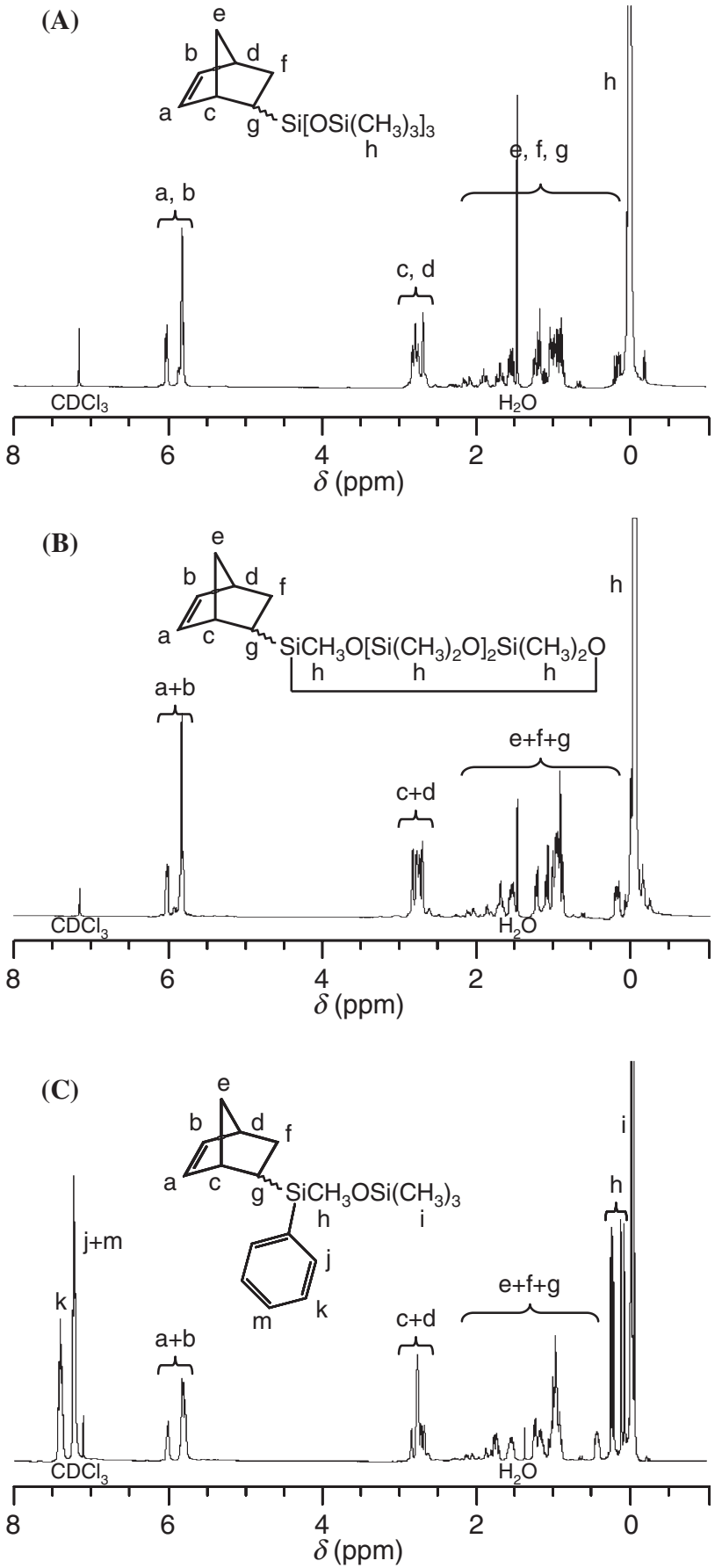

Figure 2. ${ }^{1} \mathrm{H}$ NMR spectra of NBTr (A), NBCy (B), and NBPh (C) norbornene derivatives.

1-(2-norbornen-5-yl)-1,3,3,5,5,7,7-heptamethylcyclotetrasiloxane (NBCy: endo/exo $=54 / 46$, b.p. $93^{\circ} \mathrm{C}$ at $5 \mathrm{mmHg}$, isolated yield: 78\%, G.C. purity: >99\%) (Figure 2B). ${ }^{1} \mathrm{H}$ NMR $\left(\mathrm{CDCl}_{3}\right): \delta 6.04-5.82(\mathrm{~m}, 2 \mathrm{H},-\mathrm{CH}=\mathrm{CH}), 2.86-2.74(\mathrm{~m}, 2 \mathrm{H}$, bridgehead $\equiv \mathrm{CH}), 2.14-0.20\left(\mathrm{~m}, 5 \mathrm{H},=\mathrm{CH}-\mathrm{Si}-\right.$ and $\left.-\mathrm{CH}_{2}-\right)$, $0.05-0.12$ (br s, $\left.21 \mathrm{H},-\mathrm{Si}-\mathrm{CH}_{3}\right) .{ }^{13} \mathrm{C} \mathrm{NMR}\left(\mathrm{CDCl}_{3}\right): \delta 138.4$ 134.1 ( $-\mathrm{CH}=\mathrm{CH}-$ : endo $138.4,134.4$, exo $135.8,134.1), 51.5-$ 47.0 (bridge $-\mathrm{CH}_{2}$-: endo 51.5, exo 47.0), 44.6-42.7 (bridgehead $\equiv C \mathrm{H}$ : endo 44.6 , 42.9, exo 43.0, 42.7), 27.0-26.7 (-CH 
Table I. Copolymerization of Norbornenes by Ni(acac) $)_{2} / B\left(C_{6} F_{5}\right)_{3}$. (Conditions: in toluene, total volume $=75 \mathrm{~mL}$, room temperature, time $=1.5 \mathrm{~h},\left[\mathrm{Ni}(\mathrm{acac})_{2}\right] /\left[\mathrm{B}\left(\mathrm{C}_{6} \mathrm{~F}_{5}\right)_{3}\right]=1 / 5,[\text { monomers }]_{0} /[\text { catalyst }]_{0}=1000$.)

\begin{tabular}{|c|c|c|c|c|c|c|}
\hline \multirow{2}{*}{ Run } & \multirow{2}{*}{ Polymer code } & \multirow{2}{*}{$\frac{\text { Monomer }}{\text { in feed, mol-\% }}$} & \multirow{2}{*}{$\begin{array}{c}\text { Yield } \\
\%\end{array}$} & \multirow{2}{*}{$\frac{\text { Composition }}{\text { in copolym., mol-\%a) }}$} & \multirow{2}{*}{$M_{\mathrm{n}}^{\mathrm{b})}$} & \multirow{2}{*}{$M_{\mathrm{w}} / M_{\mathrm{n}}{ }^{\mathrm{b})}$} \\
\hline & & & & & & \\
\hline 1 & $\mathrm{P}(\mathrm{NB}-\mathrm{co}-\mathrm{NBTr}) 73$ & $\mathrm{NB} / \mathrm{NBTr}=70 / 30$ & 41 & $74.2 / 25.8$ & 141,000 & 2.19 \\
\hline 2 & $\mathrm{P}(\mathrm{NB}-\mathrm{co}-\mathrm{NBT}) 82$ & $\mathrm{NB} / \mathrm{NBTr}=80 / 20$ & 65 & $85.7 / 14.3$ & 198,000 & 2.16 \\
\hline 3 & $\mathrm{P}(\mathrm{NB}-\mathrm{co}-\mathrm{NBTr}) 91$ & $\mathrm{NB} / \mathrm{NBTr}=90 / 10$ & $57^{c)}$ & $93.1 / 6.9$ & 247,000 & 2.07 \\
\hline 4 & $\mathrm{P}(\mathrm{NB}-\mathrm{co}-\mathrm{NBCy}) 73$ & $\mathrm{NB} / \mathrm{NBCy}=70 / 30$ & trace & & & \\
\hline 5 & $\mathrm{P}(\mathrm{NB}-\mathrm{co}-\mathrm{NBCy}) 82$ & $\mathrm{NB} / \mathrm{NBCy}=80 / 20$ & 26 & $86.2 / 13.8$ & 140,000 & 2.25 \\
\hline 6 & $\mathrm{P}(\mathrm{NB}-\mathrm{co}-\mathrm{NBCy}) 91$ & $\mathrm{NB} / \mathrm{NBCy}=90 / 10$ & 45 & $92.8 / 7.2$ & 151,000 & 2.12 \\
\hline 7 & $\mathrm{P}(\mathrm{NB}-\mathrm{co}-\mathrm{NBPh}) 73$ & $\mathrm{NB} / \mathrm{NBPh}=70 / 30$ & 34 & $77.2 / 22.8$ & 138,000 & 2.09 \\
\hline 8 & $\mathrm{P}(\mathrm{NB}-\mathrm{co}-\mathrm{NBPh}) 82$ & $\mathrm{NB} / \mathrm{NBPh}=80 / 20$ & 43 & $87.5 / 12.5$ & 161,000 & 2.17 \\
\hline 9 & $\mathrm{P}(\mathrm{NB}-\mathrm{co}-\mathrm{NBPh}) 91$ & $\mathrm{NB} / \mathrm{NBPh}=90 / 10$ & 46 & $92.7 / 7.3$ & 184,000 & 2.36 \\
\hline 10 & PNB & $\mathrm{NB}=100$ & $90^{d)}$ & - & & \\
\hline
\end{tabular}

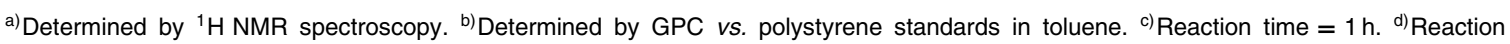
time $=15 \mathrm{~min}$.

endo 26.7, exo 27.0), 26.2-25.8 (=CH-Si-: endo 25.8, exo 26.2), $1.16\left(-\mathrm{Si}-\mathrm{CH}_{3}\right), 0.00--0.60\left(\mathrm{NB}-\mathrm{Si}-\mathrm{CH}_{3}\right)$.

5-(methylphenyltrimethylsiloxysilyl)-2-norbornene $(\mathrm{NBPh}$ racemic compound including chiral silicon: endo/exo $=45 /$ 55, b.p. $125^{\circ} \mathrm{C}$ at $5 \mathrm{mmHg}$, isolated yield: $71 \%$, G.C. purity: $>99 \%$ ) (Figure $2 \mathrm{C}) .{ }^{1} \mathrm{H}$ NMR $\left(\mathrm{CDCl}_{3}\right): \delta 7.42(\mathrm{t}, 2 \mathrm{H},-m-$ $\left.\mathrm{C}_{6} H_{5}\right), 7.24\left(\mathrm{~m}, 3 \mathrm{H},-o-\right.$ and $\left.-p-\mathrm{C}_{6} H_{5}\right), 6.01-5.79(\mathrm{~m}, 2 \mathrm{H}$, $-\mathrm{CH}=\mathrm{CH}-), 2.85-2.68(\mathrm{~m}, 2 \mathrm{H}$, bridgehead $\equiv \mathrm{CH}), 2.14-0.48$ $\left(\mathrm{m}, 5 \mathrm{H},=\mathrm{CH}-\mathrm{Si}-\right.$ and $\left.-\mathrm{CH}_{2}-\right), 0.26-0.08\left(\mathrm{~m}, 3 \mathrm{H}, \mathrm{C}_{6} \mathrm{H}_{5}-\mathrm{Si}-\right.$ $\mathrm{CH}_{3}$ ), 0.01--0.05 (s, 9H, -O-Si-CH$\left.H_{3}\right) .{ }^{13} \mathrm{C} \mathrm{NMR}\left(\mathrm{CDCl}_{3}\right): \delta$ 140.1-134.8 (-CH=CH-: endo $140.1,136.3$, exo 139.1, 134.8), 134.6-134.2 (-Si- $C \equiv$ in $\left.\mathrm{C}_{6} \mathrm{H}_{5}\right), 134.3\left(-m-C_{6} H_{5}\right), 129.9$ (-p$\mathrm{C}_{6} \mathrm{H}_{5}$ ), $128.5\left(-\mathrm{o}-\mathrm{C}_{6} \mathrm{H}_{5}\right), 52.2-47.6$ (bridge $-\mathrm{CH}_{2}-$ : endo 52.3, exo 47.6), 45.4-43.4 (bridgehead $\equiv \mathrm{CH}$ : endo 45.4, 43.4, exo 43.8, 43.4), 28.0-27.7 (- $\mathrm{CH}_{2}-:$ endo 28.0, exo 27.7), 27.3-26.9 (=CH-Si-: endo 27.3, exo 26.9), $3.00\left(-\mathrm{O}-\mathrm{Si}\left(\mathrm{CH}_{3}\right)_{3}\right), 0.12-$ $-0.40\left(\mathrm{C}_{6} \mathrm{H}_{5}-\mathrm{Si}-\mathrm{CH}_{3}\right)$.

\section{Copolymerization of Norbornenes}

A typical polymerization procedure is given below (run 2 in Table I). Ni(acac $)_{2}\left(13 \mathrm{mg}, 5.0 \times 10^{-5} \mathrm{~mol}\right), \mathrm{B}\left(\mathrm{C}_{6} \mathrm{~F}_{5}\right)_{3}(127 \mathrm{mg}$, $\left.25.0 \times 10^{-5} \mathrm{~mol}\right)$, and toluene $(60 \mathrm{~mL})$ were mixed in a $100-\mathrm{mL}$ flask via manipulation under nitrogen. The catalyst solution was then added to the toluene solution $(15 \mathrm{~mL})$ containing norbornene $(3.76 \mathrm{~g}, 0.04 \mathrm{~mol})$ and $\mathrm{NBTr}(3.89 \mathrm{~g}, 0.01 \mathrm{~mol})$, and the solution mixture was stirred at room temperature. After $90 \mathrm{~min}$, the mixture was poured into a large quantity of acetone in order to terminate the polymerization. The precipitated polymer was isolated by decantation, washed with acetone, and dried under vacuum for $5 \mathrm{~h}$ at $120^{\circ} \mathrm{C}$. Polymer yield $=65 \%$.

Poly(NB-co-NBTr) (see Figure 3). ${ }^{1} \mathrm{H} \mathrm{NMR}\left(\mathrm{CDCl}_{3}\right): \delta$ 2.5-0.7 (br m, maxima at 0.95, 1.16, 1.37, 1.71, 2.18: bicyclic unit), 0.00 (br s, $\left.-\mathrm{Si}-\mathrm{CH}_{3}\right) .{ }^{13} \mathrm{C} \mathrm{NMR}\left(\mathrm{CDCl}_{3}\right): \delta \quad 56-25$ (maxima at 30.0, 31.3, 35.4, 39.6, 41.6, 44.7, 47.3, 51.2, 52.5, 53.7: bicyclic unit), $1.95\left(-\mathrm{O}-\mathrm{Si}\left(\mathrm{CH}_{3}\right)_{3}\right) .{ }^{29} \mathrm{Si} \mathrm{NMR}\left(\mathrm{C}_{6} \mathrm{D}_{6}\right): \delta$ $7.18\left(-\mathrm{O}-\mathrm{Si}\left(\mathrm{CH}_{3}\right)_{3}\right),-66.29\left(-\mathrm{Si}\left(\mathrm{OSi}\left(\mathrm{CH}_{3}\right)_{3}\right)_{3}\right)$.
Poly(NB-co-NBCy). ${ }^{1} \mathrm{H}$ NMR $\left(\mathrm{CDCl}_{3}\right): \delta 2.5-0.7$ (br m, maxima at $0.97,1.18,1.40,1.74,2.19$ : bicyclic unit), 0.00 (br s, -Si-CH $\left.{ }_{3}\right) .{ }^{13} \mathrm{C} \mathrm{NMR}\left(\mathrm{CDCl}_{3}\right): \delta 56-25$ (maxima at 30.1, 31.3, 35.4, 39.5, 42.2, 45.1, 47.4, 51.2, 52.4, 53.7: bicyclic unit), $0.85\left(-\mathrm{Si}-\mathrm{CH}_{3}\right), \quad 0.32\left(\mathrm{NB}-\mathrm{Si}-\mathrm{CH}_{3}\right) .{ }^{29} \mathrm{Si} \mathrm{NMR}\left(\mathrm{C}_{6} \mathrm{D}_{6}\right): \quad \delta$ -19.19 (-O-Si(- $\left.\left.\mathrm{CH}_{3}\right)_{2}-\mathrm{O}-\right)$, -21.67 (-O-Si(NB)( $\left.\left.\mathrm{CH}_{3}\right)-\mathrm{O}-\right)$.

Poly(NB-co-NBPh). ${ }^{1} \mathrm{H}$ NMR $\left(\mathrm{CDCl}_{3}\right): \delta 7.42$ (br m, - m$\mathrm{C}_{6} H_{5}$ ), 7.23 (br m, -o- and $-p-\mathrm{C}_{6} H_{5}$ ), 2.5-0.7 (br m, maxima at 0.97, 1.17, 1.40, 1.71, 2.17: bicyclic unit), 0.19 (br m, $\mathrm{C}_{6} \mathrm{H}_{5}-\mathrm{Si}$ $\left.\mathrm{CH}_{3}\right), 0.00$ (br s, $\left.-\mathrm{O}-\mathrm{Si}-\mathrm{CH}_{3}\right) .{ }^{13} \mathrm{C} \mathrm{NMR}\left(\mathrm{CDCl}_{3}\right): \delta 134.1-$ $132.8\left(-\mathrm{Si}-\mathrm{C} \equiv\right.$ in $\mathrm{C}_{6} \mathrm{H}_{5}$ and $\left.-m-C_{6} H_{5}\right), 129.0\left(-p-C_{6} H_{5}\right), 127.5$ $\left(-o-C_{6} H_{5}\right), 56-25$ (maxima at 30.0, 31.4, 35.5, 39.5, 42.0, 45.3, 47.5, 51.2, 52.4, 53.7: bicyclic unit), $2.15\left(-\mathrm{Si}_{-} \mathrm{CH}_{3}\right) .{ }^{29} \mathrm{Si} \mathrm{NMR}$ $\left(\mathrm{C}_{6} \mathrm{D}_{6}\right): \delta 8.28\left(-\mathrm{O}-\mathrm{Si}\left(\mathrm{CH}_{3}\right)_{3}\right),-3.82\left(-\mathrm{Si}\left(\mathrm{CH}_{3}\right)\left(\mathrm{C}_{6} \mathrm{H}_{5}\right)-\mathrm{O}-\right)$.

\section{Analytical Procedure}

Monomers and polymers were characterized by ${ }^{1} \mathrm{H}$ NMR $(300 \mathrm{MHz}),{ }^{13} \mathrm{C} \mathrm{NMR}(75 \mathrm{MHz})$ in $\mathrm{CDCl}_{3}$ and ${ }^{29} \mathrm{Si} \mathrm{NMR}$ $(60 \mathrm{MHz})$ in the solution containing $\mathrm{C}_{6} \mathrm{D}_{6}$, toluene and $\mathrm{Cr}$ (acetylacetonate $)_{3}$ as a shiftless relaxation reagent at $23^{\circ} \mathrm{C}$ with a JNM LA-300WB spectrometer. Compositions of the copolymers were calculated from ${ }^{1} \mathrm{H}$ NMR spectra, on the basis of the peak intensities originated from siloxane unit (see Figure 3).

All molecular weight data were determined by gel-permeation chromatography at $40^{\circ} \mathrm{C}$, using a TOSOH HLC-8220 GPC system with four columns of $\mathrm{H}_{\mathrm{XL}}$ series. Toluene was used as an eluent at a flow rate of $1.0 \mathrm{~mL} \cdot \mathrm{min}^{-1}$, and a sample concentration of $5.0 \mathrm{mg} \cdot \mathrm{mL}^{-1}$ was applied. Polystyrene standards with a low polydispersity (13 standard polystyrene samples: $\left.M_{\mathrm{n}}=3840000-500, M_{\mathrm{w}} / M_{\mathrm{n}}<1.15\right)$ were used to make a calibration curve.

Thermal mechanical analysis (TMA) experiments were performed using a TMA/SS6000, SEIKO Instruments. The cast films of polymer samples were heated from 30 to $400{ }^{\circ} \mathrm{C}$ at $10^{\circ} \mathrm{C} \cdot \mathrm{min}^{-1}$ under nitrogen. 
(A)

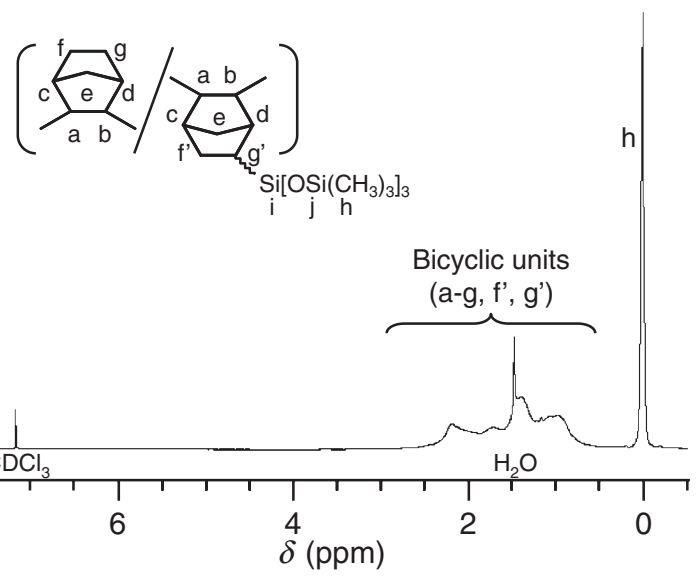

(B)
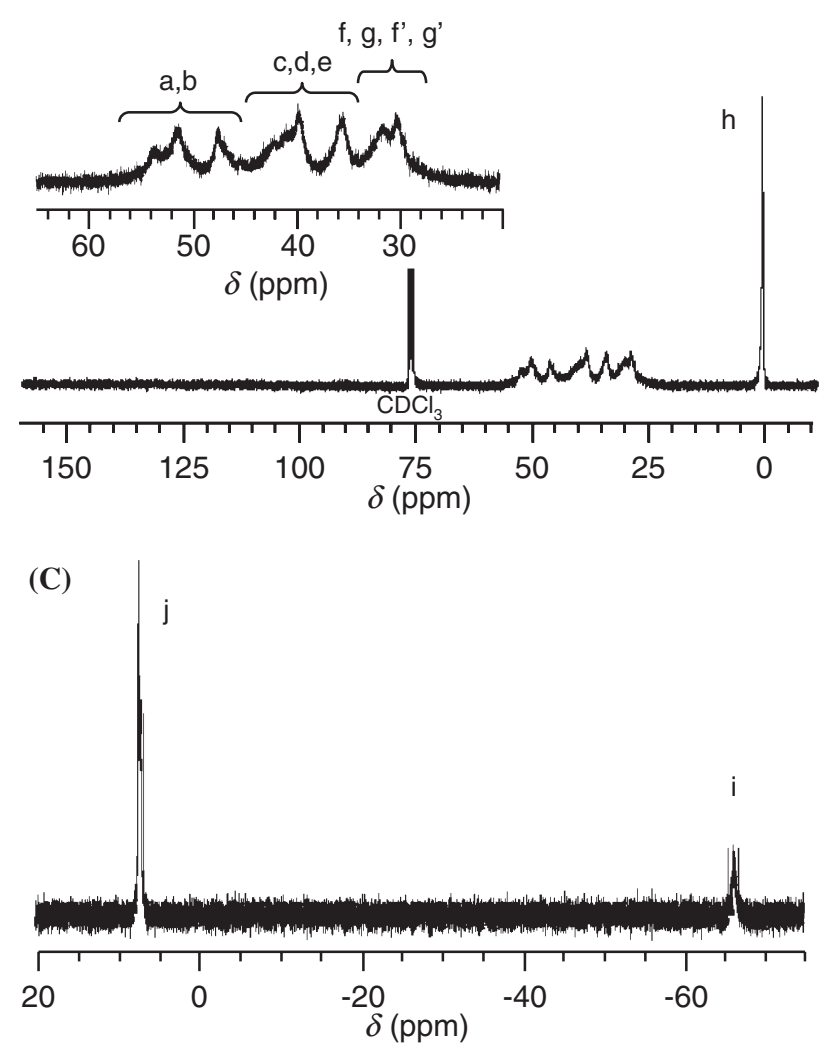

Figure 3. ${ }^{1} \mathrm{H}(\mathrm{A}),{ }^{13} \mathrm{C}(\mathrm{B})$, and ${ }^{29} \mathrm{Si}(\mathrm{C}) \mathrm{NMR}$ spectra of produced copolymer (polymer code: $\mathrm{P}(\mathrm{NB}-\mathrm{co}-\mathrm{NBTr}) 82$, run 2 in Table I).

The tensile strength and elongation at break for polymer films were determined using a tensile testing machine (STROGRAPH VE10, Toyo Seiki Seisaku-sho, LTD., Japan) at a crosshead speed of $50 \mathrm{~mm} \cdot \mathrm{min}^{-1}$. The gauge length and the sample width were $20 \mathrm{~mm}$ and $10 \mathrm{~mm}$, respectively.

The gas permeability coefficients $(P)$ of the polymer films were measured using a Rikaseiki K-315-N-01G gas permeability apparatus as $25^{\circ} \mathrm{C}$. The downstream side of the film was evacuated to $3 \mathrm{~Pa}$, while the upstream side was filled with a gas (oxygen gas) at about $1 \mathrm{~atm}\left(10^{5} \mathrm{~Pa}\right)$. The increase in pressure of the downstream receiving vessel was measured during the experiment. The $P$ values were calculated from the slopes of time-pressure curves in the steady state where Fick's law holds. ${ }^{15}$ The gas diffusion coefficients $(D)$ were determined by the time lag method using the equation: $D=l^{2} / 6 \theta$. $l$ is the film thickness and $\theta$ is the time lag, which is given by the intercept of the asymptotic line of the time-pressure curves to the time axis. The gas solubility coefficients $(S)$ were calculated by using the equation: $S=P / D$.

\section{RESULTS AND DISCUSSION}

\section{Preparation of Norbornene Derivatives}

5-tris(trimethylsiloxy)silyl-2-norbornene (NBTr), 1-(2norbornen-5-yl)-1,3,3,5,5,7,7-heptamethylcyclotetrasiloxane (NBCy), and 5-(methylphenyltrimethylsiloxysilyl)-2-norbornene $(\mathrm{NBPh})$, were synthesized following a classical DielsAlder procedure reaction. Heating at $150{ }^{\circ} \mathrm{C}$ a solution mixture of dicyclopentadiene and the corresponding vinyl-functionalized silicon compounds afforded NBTr, NBCy and $\mathrm{NBPh}$ (Figure 1), which were isolated in good yields and good purities, after purification by vacuum-distillation, respectively. Figure 2 shows the ${ }^{1} \mathrm{H}$ NMR spectra of isolated norbornene derivatives. However, they were obtained as inseparable isomeric mixtures. The endo/exo-isomer ratio for $\mathrm{NBTr}$, NBCy and NBPh were 60/40,54/46 and 45/55, respectively, as determined by integration of the proton resonances of distinct peaks (-CH=CH-: 6.10-5.70 ppm, see Figure 2). ${ }^{4}$

\section{Polymerization of Norbornene with Norbornene Deriva-} tives

For this study, the discrete binary $\mathrm{Ni}(\mathrm{acac})_{2} / \mathrm{B}\left(\mathrm{C}_{6} \mathrm{~F}_{5}\right)_{3}$ system was selected as catalyst. Not only, this system is already known to be an active catalyst for norbornene homopolymerization, ${ }^{1,16}$ it also presents the advantage of being composed of two commercially available and relatively stable components. Table I lists the results of polymerizations which were carried out in toluene at room temperature. Under these conditions, $\mathrm{Ni}(\mathrm{acac})_{2} / \mathrm{B}\left(\mathrm{C}_{6} \mathrm{~F}_{5}\right)_{3}$ initiated rapid homopolymerization of norbornene to give insoluble poly(norbornene). Although $\mathrm{Ni}(\mathrm{acac})_{2} / \mathrm{B}\left(\mathrm{C}_{6} \mathrm{~F}_{5}\right)_{3}$ did not polymerize any of the norbornene derivatives bearing siloxane group, it was found to efficiently initiate the copolymerization of norbornene with NBTr, NBCy and NBPh (Table I, run 1-9), respectively. As a single component, $\mathrm{B}\left(\mathrm{C}_{6} \mathrm{~F}_{5}\right)_{3}$ was not active in homo- and copolymerizations of the norbornenes under these conditions, strongly indicating that these polymerizations catalyzed by the $\mathrm{Ni}(\mathrm{acac})_{2} / \mathrm{B}\left(\mathrm{C}_{6} \mathrm{~F}_{5}\right)_{3}$ system are not cationic.

Hence, three series of copolymers, $\mathrm{P}(\mathrm{NB}-\mathrm{co}-\mathrm{NBTr}), \mathrm{P}(\mathrm{NB}-$ co-NBCy) and $\mathrm{P}(\mathrm{NB}-c o-\mathrm{NBPh})$, were obtained. Unlike the homopoly(norbornene) obtained in run 10 (Table I), ${ }^{16}$ the copolymers were all soluble in toluene and THF. The copolymers obtained from more than $20 \mathrm{~mol} \% \mathrm{NBTr}$ and NBCy feedings were also soluble in aliphatic solvent such hexane and decane, but insoluble in dichloromethane. This contrasts with the copolymers from NBPh feeding which showed good solubility in dichloromethane. The copolymers have high 
Table II. Homopolymerization and Copolymerization of Norbornene Derivatives by $\mathrm{Ni}(\mathrm{acac})_{2} / \mathrm{B}\left(\mathrm{C}_{6} \mathrm{~F}_{5}\right)_{3}$. $($ Conditions: in toluene, total volume $=75 \mathrm{~mL}$, reaction temperature $=50^{\circ} \mathrm{C},\left[\mathrm{Ni}(\mathrm{acac})_{2}\right] /\left[\mathrm{B}\left(\mathrm{C}_{6} \mathrm{~F}_{5}\right)_{3}\right]=1 / 5,[\text { monomers }]_{0} /[\text { catalyst }]_{0}=1000$.)

\begin{tabular}{|c|c|c|c|c|c|c|c|}
\hline \multirow{2}{*}{ Run } & \multirow{2}{*}{ Polymer code } & \multirow{2}{*}{$\begin{array}{c}\text { Monomer } \\
\text { in feed, mol-\% }\end{array}$} & \multirow{2}{*}{$\begin{array}{c}\text { Time } \\
\mathrm{h}\end{array}$} & \multirow{2}{*}{$\begin{array}{c}\text { Yield } \\
\%\end{array}$} & \multirow{2}{*}{$\begin{array}{c}\text { Composition } \\
\text { in copolym., mol-\%a) }\end{array}$} & \multirow{2}{*}{$M_{\mathrm{n}}{ }^{\mathrm{b})}$} & \multirow{2}{*}{$M_{\mathrm{w}} / M_{\mathrm{n}}{ }^{\mathrm{b})}$} \\
\hline & & & & & & & \\
\hline 1 & PNBTr & $\mathrm{NBTr}=100$ & 12.0 & 28 & - & 29,000 & 2.10 \\
\hline 2 & PNBCy & $\mathrm{NBCy}=100$ & 12.0 & 12 & - & 27,000 & 2.15 \\
\hline 3 & PNBPh & $\mathrm{NBPh}=100$ & 12.0 & 45 & - & 42,000 & 2.00 \\
\hline 4 & $\mathrm{P}(\mathrm{NB}-\mathrm{co}-\mathrm{NBTr}) 28$ & $\mathrm{NB} / \mathrm{NBTr}=20 / 80$ & 12.0 & 37 & $26.6 / 73.4$ & 46,000 & 2.05 \\
\hline 5 & $\mathrm{P}(\mathrm{NB}-\mathrm{co}-\mathrm{NBT}) 46$ & $\mathrm{NB} / \mathrm{NBTr}=40 / 60$ & 3.0 & 65 & $46.1 / 53.9$ & 52,000 & 2.35 \\
\hline 6 & $\mathrm{P}(\mathrm{NB}-\mathrm{co}-\mathrm{NBT}$ ) 64 & $\mathrm{NB} / \mathrm{NBTr}=60 / 40$ & 3.0 & trace $^{c)}$ & & & \\
\hline
\end{tabular}

a) Determined by ${ }^{1} \mathrm{H}$ NMR spectroscopy. ${ }^{\text {b) }}$ Determined by GPC vs. polystyrene standards in toluene. ${ }^{c}$ Polymerization was carried out at room temperature.

Table III. Thermal, Mechanical, and Transport Properties of the Poly(norbornene)s with Siloxane Substituents

\begin{tabular}{|c|c|c|c|c|c|}
\hline \multirow{2}{*}{ Polymer code } & $T_{\mathrm{g}}^{\mathrm{a})}$ & $\begin{array}{l}\text { Tensile strength } \\
\text { at break }\end{array}$ & $\begin{array}{l}\text { Elongation }^{\text {b) }} \\
\text { at break }\end{array}$ & $P\left(\mathrm{O}_{2}\right)^{\mathrm{c})}$ & $D\left(\mathrm{O}_{2}\right)^{\mathrm{d})}$ \\
\hline & ${ }^{\circ} \mathrm{C}$ & $\mathrm{MPa}$ & $\%$ & Barrer & $10^{-7} \mathrm{~cm}^{2} / \mathrm{s}$ \\
\hline $\mathrm{P}(\mathrm{NB}-\mathrm{co}-\mathrm{NBTr}) 73$ & 304 & 31 & 7 & 239 & 19.0 \\
\hline $\mathrm{P}(\mathrm{NB}-\mathrm{co}-\mathrm{NBT}) 82$ & 343 & 39 & 6 & 82 & 5.2 \\
\hline $\mathrm{P}(\mathrm{NB}-\mathrm{co}-\mathrm{NBT}) 91$ & 360 & 67 & $<1$ & 39 & 2.4 \\
\hline $\mathrm{P}(\mathrm{NB}-\mathrm{co}-\mathrm{NBCy}) 82$ & 293 & 43 & 6 & 28 & 2.6 \\
\hline P(NB-co-NBCy) 91 & 320 & 62 & $<1$ & 19 & 1.9 \\
\hline $\mathrm{P}(\mathrm{NB}-\mathrm{co}-\mathrm{NBPh}) 73$ & 265 & 52 & 14 & 22 & 2.7 \\
\hline $\mathrm{P}(\mathrm{NB}-\mathrm{co}-\mathrm{NBPh}) 82$ & 327 & 62 & 5 & 15 & 1.7 \\
\hline $\mathrm{P}(\mathrm{NB}-\mathrm{co}-\mathrm{NBPh}) 91$ & 341 & 71 & $<1$ & 12 & 1.4 \\
\hline
\end{tabular}

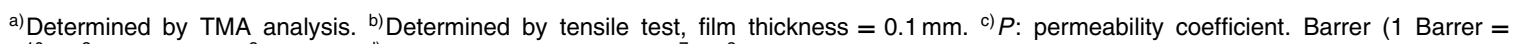
$10^{-10} \mathrm{~cm}^{3}$ (STP) $\mathrm{cm} / \mathrm{cm}^{2} \mathrm{~s} \mathrm{cmHg}$ ). ${ }^{\text {d) }} D$ : diffusion coefficient, $10^{-7} \mathrm{~cm}^{2} / \mathrm{s}$.

molecular weights $\left(M_{\mathrm{n}}=138000-247000\right)$ and narrow molecular weight distributions $\left(M_{\mathrm{w}} / M_{\mathrm{n}}=2.07-2.36\right)$, which in all cases were unimodal. These results strongly suggest that these products are copolymers, and that homopoly(norbornene) was not formed. Actually, reaction time was kept low to avoid any possible formation of poly(norbornene).

The copolymers were formed via vinyl addition polymerization as evidenced by ${ }^{1} \mathrm{H}$ and ${ }^{13} \mathrm{C}$ NMR analyses. Figure 3 shows the typical NMR spectra of the copolymer. The compositions of all copolymers were determined by ${ }^{1} \mathrm{H}$ NMR spectroscopy (see Figure 3). Contents of the comonomers in copolymers were almost proportional to the monomer feed ratios. But high comonomer feeding resulted in lower polymer yields. The highest yields of copolymers were obtained with NBTr as comonomer, compared to NBCy and NBPh, suggesting that the structures of siloxane substituent have a certain impact on the catalytic performance, although little in the copolymer composition. The ${ }^{29} \mathrm{Si}$ NMR analyses showed that cleavage and/or cross-linking reactions at the siloxane groups did not occur during polymerization reaction (see Figure $3 \mathrm{C}$ ).

Table II lists the results of polymerizations performed at $50{ }^{\circ} \mathrm{C}$. Under these conditions, $\mathrm{Ni}(\mathrm{acac})_{2} / \mathrm{B}\left(\mathrm{C}_{6} \mathrm{~F}_{5}\right)_{3}$ could initiate the homopolymerization of norbornene derivatives bearing siloxane group. The formation of these polymers via vinyl addition was confirmed by NMR spectroscopy. The copolymers with high NBTr unit contents up to $50 \mathrm{~mol} \%$, which were almost proportional to the feed ratios, were obtained in moderate yields. The polymers have relatively low molecular weights $\left(M_{\mathrm{n}}=27000-52000\right)$ but narrow and unimodal molecular weight distributions $\left(M_{\mathrm{w}} / M_{\mathrm{n}}=2.00\right.$ 2.35). Unlike the copolymerizations carried out at room temperature, $\mathrm{NBPh}$ showed higher activity in homopolymerization as compared to NBTr and NBCy (Table II, run 1-3). These results indicate that the steric and electronic features of siloxane groups, relating to the mobility, play a significant role in the addition polymerization process. All polymers have a good solubility in toluene, THF as well as hexane. In addition, homo- and copolymer of NBTr were found soluble in oligosiloxane solvents such decamethyltetrasiloxane and decamethylcyclopentasiloxane.

\section{Thermal and Mechanical Properties of Poly(norbornene) with Siloxane Substituents}

Table III lists the thermal and mechanical properties of the poly(norbornene)s with siloxane substituents. Transparent films for all polymers were prepared by casting a toluene solution of the polymers onto glass. Films obtained for the polymers with high siloxane group content were, however, breakable and brittle due to the low molecular weights, and therefore could not be analyzed. According to TMA, the polymers possess high 
Table IV. Oxygen Gas Permeability of Silicon-Containing Poly(norbornene)s

\begin{tabular}{|c|c|c|c|c|c|}
\hline \multirow{2}{*}{ Polymer code } & \multirow{2}{*}{ Type } & Substituent & Composition & $P\left(\mathrm{O}_{2}\right)^{\mathrm{a})}$ & \multirow{2}{*}{ ref } \\
\hline & & M1/M2 & M1/M2 (mol-\%) & Barrer & \\
\hline PNB & & $\mathrm{H}$ & & 10.8 & 17 \\
\hline $\mathrm{P}(\mathrm{NB}-\mathrm{co}-\mathrm{NBTr}) 73$ & & $\mathrm{H} / \mathrm{Si}\left(\mathrm{OSiMe}_{3}\right)_{3}$ & $74.2 / 25.8$ & 239 & this work \\
\hline $\mathrm{P}(\mathrm{NB}-\mathrm{co}-\mathrm{NBT}) 82$ & AP & $\mathrm{H} / \mathrm{Si}\left(\mathrm{OSiMe}_{3}\right)_{3}$ & $85.7 / 14.3$ & 82 & this work \\
\hline APNSi & & $\mathrm{SiMe}_{3}$ & & 980 & 12 \\
\hline ACPNHSi & & $\mathrm{C}_{6} \mathrm{H}_{13} / \mathrm{SiMe}_{3}$ & $58 / 42$ & 60 & 12 \\
\hline PNB & & $\mathrm{H}$ & & 2.8 & 18 \\
\hline PTMSNB & ROMP & $\mathrm{SiMe}_{3}$ & & 30 & 18 \\
\hline PDSNB & & $\mathrm{SiMe}_{2} \mathrm{CH}_{2} \mathrm{SiMe}_{3}$ & & 16 & 18 \\
\hline
\end{tabular}

a) $P$ : permeability coefficient. Barrer (1 Barrer $=10^{-10} \mathrm{~cm}^{3}(\mathrm{STP}) \mathrm{cm} / \mathrm{cm}^{2} \mathrm{~s} \mathrm{cmHg}$ ).

to very high glass-transition temperatures $\left(T_{\mathrm{g}}\right)$, ranging from 265 to $360^{\circ} \mathrm{C}$. The highest $T_{\mathrm{g}}$ was obtained for $\mathrm{P}(\mathrm{NB}-\mathrm{co}-$ NBTr) copolymers at low concentration of NBTr. The smallest $T_{\mathrm{g}}$ was obtained for $\mathrm{P}(\mathrm{NB}-\mathrm{co}-\mathrm{NBPh})$ copolymers with the highest $\mathrm{NBPh}$ incorporation $(22.8 \mathrm{~mol}-\%)$. These results suggest that $T_{\mathrm{g}}$ of the copolymers can be tuned according to the nature and content of the comonomer. Despite having a very high $T_{\mathrm{g}}$, the films of the polymers displayed good flexibility at room temperature, showing that siloxane groups linked to the polymer chain improves the processing and the mechanical properties. The tensile test showed that at high comonomer content in polymers, the elongation at break increased, while the tensile strength tended to decrease. The copolymers having the phenyl siloxane groups $\mathrm{P}(\mathrm{NB}-\mathrm{co}$ $\mathrm{NBPh}$ ) possess the highest tensile strength, ranging from 52 to $71 \mathrm{MPa}$.

\section{Gas Permeation Properties of Poly(norbornene) with} Siloxane Substituents

The transport property of the copolymers was evaluated by monitoring the oxygen gas permeability of their films. Table III lists the oxygen permeability $P\left(\mathrm{O}_{2}\right)$ and diffusion $D\left(\mathrm{O}_{2}\right)$ coefficients of the poly(norbornene)s with siloxane substituents. The oxygen permeability of the copolymers is dependent on the contents of the comonomer units, and generally increases with high content of comonomer in the copolymers. While slight changes were observed for the $P\left(\mathrm{O}_{2}\right)$ values of $\mathrm{P}(\mathrm{NB}-\mathrm{co}-\mathrm{NBCy})$ and $\mathrm{P}(\mathrm{NB}-\mathrm{co}-\mathrm{NBPh})$ copolymers, the $P\left(\mathrm{O}_{2}\right)$ values greatly increased on going from $\mathrm{P}(\mathrm{NB}-\mathrm{co}-$ NBTr)91 to $\mathrm{P}(\mathrm{NB}-\mathrm{co}-\mathrm{NBTr}) 73$ (39 to 239 Barrer). The results suggest that the structures of siloxane substituents, three arm-, cyclic-, and phenyl-siloxane groups, play an important role in the gas transport properties of the polymer films.

The oxygen permeability coefficients for various types of silicon-containing poly(norbornene)s are listed in Table IV. It has been reported that the introduction of $\mathrm{SiMe}_{3}$ group in poly(norbornene) results in a significant increase in a gas permeability, ${ }^{12,18}$ and as a results of WAXD and PALS analysis, it was concluded that such behavior was ascribed to an increase in the free volume. Furthermore, the effect of the substituent on gas permeability was much stronger for addition-type poly(norbornene), compared to ROMP-type, relating to the rigidity of the backbone. As mentioned above, incorporation of $\mathrm{Si}\left(\mathrm{OSiMe}_{3}\right)_{3}$ group into poly(norbornene) could greatly improve the oxygen permeability, and the diffusion coefficient $D\left(\mathrm{O}_{2}\right)$ was found to increase markedly with high $\mathrm{Si}\left(\mathrm{OSiMe}_{3}\right)_{3}$ content in the polymer (see Table III). Since the geometric densities of these polymer series have not been defined, further research is needed to elucidate the relations between the substituent structure and transport property. However, these results indicate that the introduction of $\mathrm{Si}\left(\mathrm{OSiMe}_{3}\right)_{3}$ group in main chain leads to polymer with higher free volume. The side chain with both flexible $\mathrm{Si}-\mathrm{O}$ linkages and bulk $\mathrm{SiMe}_{3}$ groups, which are moving in the material, may control the diffusibility of the permeating gas. Similar gas permeation behaviors have been reported previously for oligosiloxane-substituted polymers such as polystyrene, ${ }^{19,20}$ polyimide, ${ }^{21,22}$ and polyacetylene..$^{23-25}$

\section{CONCLUSION}

New poly(norbornene)s with the siloxane substituents were successfully synthesized by vinyl addition polymerizations using the binary $\mathrm{Ni}(\mathrm{acac})_{2} / \mathrm{B}\left(\mathrm{C}_{6} \mathrm{~F}_{5}\right)_{3}$ system. The copolymers showed good solubility in common organic solvents and very high glass-transition temperatures, up to $265^{\circ} \mathrm{C}$. The $T_{\mathrm{g}}$ was found dependent on the content and structure of the comonomer units. The incorporation of siloxane groups in the chain resulted in the improvement of the mechanical properties, and the copolymer films showed high flexibility. In addition, oxygen gas permeabilities for the copolymer films were found to be also dependent on both the content and structure of the siloxane groups, and the films for the polymers with $\mathrm{Si}\left(\mathrm{OSiMe}_{3}\right)_{3}$ group showed high oxygen permeability in the range of 39 to 239 Barrer. The finding suggests that the material properties can be regulated within the present polymerization system by using suitable monomer substituents, and that the addition-type poly(norbornene)s with siloxane substituents can be considered as an interesting candidate for membrane materials in packaging, cosmetics and medical care. Further studies on this interesting polymer groups are now in progress. 
Acknowledgment. We appreciate the assistance provided by Dr. N. Matsumoto for monomer preparations and by Dr. Y. Yamane for NMR spectroscopy measurements at ShinEtsu Chemical Co., Ltd. We are very grateful to Dr. O. Tardif for the critical reading of manuscript at the RIKEN Institute.

Received: January 15, 2009 Accepted: April 26, 2009 Published: June 17, 2009

\section{REFERENCES}

1. C. Janiak and P. G. Lassahn, Macromol. Rapid Commun., 22, 479 (2001).

2. B. S. Heinz, F. P. Alt, and W. Heitz, Macromol. Rapid Commun., 19, 251 (1998).

3. B. G. Shin, M. S. Jang, D. Y. Yoon, and W. Heitz, Macromol. Rapid Commun., 25, 728 (2004).

4. S. Breunig and W. Risse, Makromol. Chem., 193, 2915 (1992).

5. A. Reinmuth, J. P. Mathew, J. Melia, and W. Risse, Macromol. Rapid Commun., 17, 173 (1996).

6. J. P. Mathew, A. Reinmuth, J. Melia, N. Swords, and W. Risse, Macromolecules, 29, 2755 (1996).

7. B. L. Goodall, G. M. Benedikt, L. H. McIntosh, D. A. Barnes, and L. F. Rhodes, International Patent WO 95/14048 (1995).

8. B. L. Goodall, International Patent WO 96/37526 (1996).

9. L. H. McIntosh, B. L. Goodall, and R. A. Shick, International Patent WO 97/20871 (1997).

10. N. R. Grove, P. A. Kohl, S. A. B. Allen, S. Jayaraman, and R. A. Shick, J. Polym. Sci., Part B: Polym. Phys., 37, 3003 (1999).

11. K. D. Dorkenoo, P. H. Peromm, and M. E. Rezac, J. Polym. Sci., Part
B: Polym. Phys., 36, 797 (1998).

12. E. S. Finkelshtein, K. L. Makovetskii, M. L. Gringolts, Y. V. Rogan, T. G. Golenko, L. E. Starannikova, Y. P. Yampol'skii, V. P. Shantarovich, and T. Suzuki, Macromolecules, 39, 7022 (2006).

13. S. Kaita, K. Matsushita, M. Tobita, Y. Maruyama, and Y. Wakatsuki, Macromol. Rapid Commun., 27, 1752 (2006).

14. "The Analytical Chemistry of Silicones," A. L. Smith, Ed., Wiley, New York, 1991.

15. a) R. M. Barrer, Trans. Faraday Soc., 35, 628 (1939).

b) S. A. Stern, in "Membrane Separation Processes" P. Meares, Ed., Elsevier, New York, 1976.

16. D. A. Barnes, G. M. Benedikt, B. L. Goodall, S. S. Huang, H. A. Kalamarides, S. Lenhard, L. H. McIntosh, K. T. Selvy, R. A. Shick, and L. F. Rhodes, Macromolecules, 36, 2623 (2003).

17. C. T. Zhao, M. do Rosário Ribeiro, M. N. de Pinho, V. S. Subrahmanyam, C. L. Gil, and A. P. de Lima, Polymer, 42, 2455 (2001).

18. V. I. Bondar, Y. M. Kukharskii, Y. P. Yampol'skii, E. S. Finkelshtein, and K. L. Makovetskii, J. Polym. Sci., Part B: Polym. Phys., 31, 1273 (1993).

19. Y. Kawakami, T. Aoki, H. Hisada, Y. Yamamura, and Y. Yamashita, Polym. Commun., 26, 133 (1985).

20. Y. Kawakami and I. Imae, Macromol. Chem. Phys., 200, 1245 (1999).

21. Y. Nagase, S. Mori, M. Egawa, and K. Matusi, Mackromol. Chem., 191, 2413 (1990).

22. Y. Nagase, T. Ando, and C. M. Yun, React. Funct. Polym., 67, 1252 (2007).

23. T. Aoki, H. Nakahara, and E. Oikawa, Polym. Prepr., Jpn., 41, 4036 (1992).

24. T. Aoki, K. Suzumura, T. Kaneko, and E. Oikawa, Polym. Prepr., Jpn., 46, 2159 (1997).

25. T. Aoki, K. Suzumura, T. Kaneko, and M. Teraguchi, Polymer, 47, 4867 (2006). 